\title{
The Suitability of a Transcultural Clinical Approach to Psychosomatic Disturbances in Reunion Island
}

\author{
Ingrid Rassaby-Darsanesing ${ }^{1,2}$, Antoine Bioy ${ }^{1,3,}{ }^{*}$, Jean-Claude Lavaud ${ }^{1,4}, \&$ Christelle Viodé ${ }^{1}$ \\ ${ }^{1}$ Université de Bourgogne Franche-Comté, Besançon, France \\ ${ }^{2}$ Etablissement Public de Santé Mentale de La Réunion, Réunion, France \\ ${ }^{3}$ Centre de Formation et d'Étude en Hypnose IPNOSIA, Bayonne, France \\ ${ }^{4}$ Centre de Ressources et d'Etudes Ericksoniennes de la Réunion (CREER), Réunion, France
}

\begin{abstract}
Cultural foundations, beliefs and associated ritual practices delimit the relation to and the representation and lived experience of the body in specific ways. Language is the means through which the cultural specificity of both individual and shared mental content can be explored and worked with in therapy. This article presents beliefs about the body in a patient's religion of origin and takes up the question of the role of the cultural dimension in psychosomatic phenomena. A case report gives indications of a novel therapeutic approach to this theme and highlights the intrinsic connection between cultural belonging and embodiment. Both the two-year long clinical intervention and analysis are grounded in transcultural and psychodynamic theories. The analysis shows how important it is to be aware of the patients' cultural background and the resonance of history in the patients' civilization.
\end{abstract}

KEYWORDS: culture, embodiment, language, psychosomatic disturbance, Reunion Island (Réunion)

\section{A Pertinência de uma Abordagem Clínica Transcultural a Distúrbios Psicossomáticos na llha Réunion}

\begin{abstract}
RESUMO - Bases culturais, crenças e práticas rituais associadas delimitam a relação, a representação e a experiência vivida do corpo de formas específicas. A linguagem é o meio através do qual a especificidade cultural dos conteúdos mentais individuais e partilhados podem ser explorados e trabalhados em terapia. Este artigo apresenta as crenças sobre o corpo segundo a religião de origem de um paciente e levanta a questão do papel da dimensão cultural no fenômeno psicossomático. Um relato de caso dá indicações de uma nova abordagem terapêutica para esse tema e destaca a conexão intrínseca entre pertencimento cultural e corporificação. Tanto a intervenção clínica, que durou dois anos, como a análise fundamentaram-se nas teorias transcultural e psicodinâmica. A análise demonstra como é importante estar ciente sobre o contexto cultural dos pacientes e sobre a ressonância da história na civilização dos pacientes.
\end{abstract}

PALAVRAS-CHAVE: cultura, corporificação, linguagem, distúrbio psicossomático, Ilha Réunion

\section{INTRODUCTION:THE MINGLING OF CULTURES}

On the multicultural island of Réunion, the mingling of identities continues to be represented in a particularly active manner, in a constant dialogue among a shared collective culture, individual beliefs, and realignments specific to the lived experience of the body.
This cultural mix is constructed first and foremost from the original cultures of those who were immigrants, but it does not occur in a simple, fluid, or linear process. These immigrants include captives from East Africa, Malaysians, Polynesians, indigenous Australians and Chinese (Pourchez,

*Email: antoine.bioy@gmail.com 
2005), among a huge majority of slaves from Madagascar and Africa. The rules in force at the time when slaves were imported onto an island that was already inhabited have functioned as limits on the expression, perpetuation and transmission of the majority of cultures. For example, one rule stipulated that slaves of the same origin were to be separated from each other; another mandated the intermixing of rival ethnic groups, thus enabling the homeostasis of the system of French domination to be maintained (it became impossible to organize a revolt, which required a minimal degree of alliance).

Further, the evangelical mission of the French colonists pushed a great number of immigrants to give up their religious affiliations and their attendant cultural foundations, in order to become "respectable" in terms of new social codes. Lastly, the traumatic effects of the slave trade (which constantly find resonances in contemporary events) have also contributed to the multifactorial picture of the identities inherited by the inhabitants of Réunion.

On the island, cultural mixing is primarily based on the heritage of the European, Madagascan and South Indian communities (Pourchez, 2005). The culture of Réunion has derived its own symbolism and identity essentially from the intersection of South Indian and Madagascan traditions; this can be seen in the presence -in private courtyards, on roadsides or in the hollows of cliffs - of small altars devoted to deities that everyone recognizes, and which are called upon in prayers and rituals. Religion is omnipresent and widely embraced throughout Réunion; what is important is not the choice of one particular religion over another, but adhering to a general belief system. Adhering to this form of syncretism is a major constitutive element of Réunion identity. This syncretism starts with the spoken languages: French (official spoken language) and Reunionese Creole. Although Creole is deeply rooted in French vocabulary and widely spoken, it only has been acknowledged as a language for a few years.

Nowadays French influences can also be found in the existence of French institutions (schools, hospitals, law courts...), where French language is usually spoken and people are asked to learn as Europeans, no matter their own beliefs. Although they were once accepted (in the 1950's, after the Departmentalization), it now seems that some Creoles would like to put French influences aside, except for catholicism that is deep-rooted in Réunion. Médéa (2003) says that "for the last five to ten years, they [the cultural identities] have been rebuilding themselves throughout, for example, the Tamil Renewal, the kaf, zarab, chinois identities, etc..." (p. 6). Does this phenomenon result from a conscious will, or does it have to do with a more unconscious collective attempt to remember the horrible traumas from slavery, to prevent them from happening again and to avoid identifying with the attacker? On the contrary, Médéa also points out that the youngsters react to the cultural globalization and are particularly sensitive to Afro-American culture.

As Benoist (1996) theorized about "creolization": "it describes a process and not a state" (para. 34). This could mean that the identity motion is somehow unpredictable and goes many different ways, inclined to worldwide stimulations.

\section{THE ROLE OF THE BODY IN TREATMENT}

Clinical practice shows that, for many inhabitants of Réunion, chronic conditions such as diabetes or pain syndromes, degenerative diseases and visceral pain follow a common "thread": if certain rituals are not observed, the body is invaded by ancestral or demonic entities. Réunion is not, however, a traditional society; Western medicine stands alongside, interacting with and also gradually supplanting ancestral representations. The plurality of treatments available is, in a certain sense, indicative of the range of ways in which the body is experienced and of the intersecting processes that influence this, which can sometimes be quite complex to decipher. The very large number of religious observations set the pace of the year, and traditional practices still remain very present. As heir to these influences, the Creole language of Réunion, in its structure and syntax, its neologisms and what it leaves unsaid, is suffused with all of this diversity and experience and with the ongoing progress towards the construction of identity.

For example, the body is thought of as a concrete and tangible substratum by means of which the sacred and profane worlds interact with one another. It is thought to be fragile, because it can be attacked by evil spirits. In Réunion culture, a "zespri" or a "bébèt" can be the source of the mental and somatic disturbances of the person whom it possesses. It is important to take care of the body, especially because of its fragility; the adage mens sana in corpore sano is fully integrated into local culture, although with the qualification that it is also necessary to have a "contented ancestor" watching benevolently over one.

Cultural mixing and Western contributions to the perception of self and world have been key factors in a certain watering-down or even loss of ritual practices. There is thus a wide range of positions and contradictory movements in relation to the question of identity (Bonniol, 2001); between modernization and affirmations of identity, people in Réunion are constantly working to define themselves as persons, individuals and subjects.

Some are very devout and observant, and others become atheists or simply non-practicing believers. What persists, with a greater or lesser degree of subtlety, is a profound belief in the interplay between the sacred and the profane, which manifests itself in different forms. 


\section{THE RELATIONTO SELF AND THE WORLD IN HINDU TRADITIONS IN RÉUNION}

We are going to focus on the representations and consequences of Hindu traditions, which were involved in the clinical situation we shall present in this article. In the culture of Réunion, rituals seek to maintain the unity of body and psyche even prior to the conception of a child. They accompany the in utero development of the fetus and childbirth, as well as the moments that are identified as crucial to life and death, depending on the particular cultures (Govindama, 2011; Grandidier, 1932). The symbolic dimension of culture borne by these rituals serves to recall the connection to a founding myth, which is linked to the deity that reigns over a family and acts as an anchoring point for affiliation and for respect among generations. For example, rituals practiced during pregnancy seek to differentiate the body of the infant-to-be from the mother's body and to enter this infant into the lineage of the generations. These rituals allow the (immortal) soul to become incarnate and thus, the fetus to be recognized as mortal. It should be noted that in Hindu culture, filiation is limited to the paternal line, which fundamentally marks out an area of determinism in the lived experience of identity (as will be the case for the patient discussed below).

Hindu rituals act upon the body but focus on the integrity of the soul; this soul preexists the body and subsists after its death, for earthly life is only a passage that allows the soul to evolve and to emancipate itself gradually from earthly interests, in a process that culminates in Brahmanism (Tarabout, 2012). In the Hindu view of conception, the father's sperm provides the bones, the flesh and the blood, which are consolidated in the mother's uterus and form the future baby; the soul comes to the body when the gametes of the mother and father meet. Following this, the rituals of pregnancy are aimed not only at guaranteeing the continuing development of the embryo/fetus, but also at protecting the infant from the "ambivalence of maternal feelings" including fantasies of infanticide (Govindama, 2002) - and assigning a place to the father. The regulative function of social roles in these rituals is already evident here.

Govindama (2011) describes the requirements and prohibitions that intervene, among the Tamils of Réunion, throughout a lifetime and even before a life exists. We would add that, for the most devout Tamils, these practices must be authorized formally by an astrologist who has previously determined propitious and inauspicious dates for each act concerned (rituals, ceremonies, marriage, conception, weekly fasting, the beginning and end of specific diets). These rituals, which involve mental and physical health, provide families with both eating habits and a moral sense, and will one day be inherited by the child-to-be. "The karman $^{1}$ of the fetus will depend on those of the parents who welcome it and on their respective ancestral lines" (2011, p. 42). This underscores the transgenerational structure that, along with the Hindu understanding of sacrifice, fosters the likelihood that descendants will have a good life.

All of these data are in accord with anthropological theories about the notion of personhood: the latter issues essentially from material (physical) and immaterial (spiritual) components. This definition is reminiscent of the eternal dualism of body and mind, which together are the heirs of the family's history, society and culture. While it is fairly common to define oneself in terms of one's name, status, background and religion, self-definition based on an approach to the body is unusual; however, that is the case here. Examining the existence of the body in Réunion Creole allows us to get a better grasp of the subject's perception of intimate experience.

\section{HOW THE BODY IS DESIGNATED INTHE CREOLE LANGUAGE}

Whether written or spoken, language constitutes both a trace and a perpetuation of a history and a relation to the world. In Réunion, speech is marked by the prevalence of metaphors involving flora and fauna. This leads us to wonder how Réunion Creole denotes and depicts the body. Are there specific meanings in this area? In other words, how does Creole culture breathe life into the body through maxims, proverbs and other sayings?

When a part of the body is spoken of in Creole, it is dissociated syntactically from the rest of the body and becomes a distinct entity, which is inappropriate in French: "mon tèt'i fé mal" (literally meaning "my head hurts" is used to say "I've got a headache"); "ma la casse mon jamb" ("I broke my leg" or "my leg is broken"); "la tèt' la pas bon" ("his/her head isn't right" or "he's/she's crazy"); “noulafépèt' nout'vent"' ("we made our tummy explode," which means "we ate too much"); "larg'palokor" (literally "don't let your body down", is used to say "don't give up").

The parts of the human body are often named with words relating to animals: "le zhabo" (jabot or crop of a bird) = the throat; "le kolé" (neck of chicken or other fowl) = the neck; "la patte" (an animal's leg) is a familiar term for the leg; "le nazo" (the nostril of a cow) = nostrils, nose.... It is also common to hear the word "femèl" (= female) used in place of "woman" and " $m a ̂ l$ " for "man"; these terms can have either a pejorative connotation (the name of an animal

1 Monier-Williams (1899) defines this term as follows: a "former act leading to inevitable results, fate" (p. 258). 
can be added to them to form an insult, "femel lechien" or "female dog") or, on the contrary, can express affection ("un mâl matou" or "male cat" = a loved one or lover).

Most Réunion Creole maxims and proverbs refer to animals, plants, and substances rather than the human body. For example:

- "zoreilcochondann' marmite pois" = "pigs' ears in the pot of peas [don't hear or understanding anything]", or "do lo sufèysonge" = "water on the taro leaf [slides off and doesn't stick]." These two expressions refer to the need not to pay too much attention to remarks, criticisms and events that are out of our hands or are not very important.

- "bèfmor, ilès la mizèrpou son po" = "when a poor guy" (a bull, here) "dies, the poverty and misery" he brings to an end attack his wife and children, as represented by his "hide" (Honoré, 2002), and

- "margozléamer, maislogrinlédou" = "the bitter melon [Momordicacharantia or "bitter melon" is bitter but its seed is sweet," which is the equivalent of English expression “you can't judge a book by its cover."

The sayings and proverbs that do mention the human body often involve a degree of violence, such as "zenfan $y$ yem som'le kèr, y dresse som 'la main" (= "you love a child with your heart, but you educate him with your hand") or "cet'y donn' chabouk y rale pas charett" (= "nobody who uses the whip has to pull the cart"). "Change la chair," (literally "to change flesh") means to "change lovers." The triviality of representations of the body's role in the sexual act can be astonishing.

Anatomical displacements sometimes occur in Réunion Creole, in comparison with French. For example, "le lestoma" (the stomach) commonly means the "chest", or the upper thorax, which is certainly home to the stomach, but also to the heart. By extension, in colloquial speech, "stomach" comes to designate the heart, as in the expression "mon lestoma i batt' kart", which literally means "my stomach is beating cards"; the movement, sound and rhythm of shuffling playing cards represent the pounding of the heart when we are afraid. Thus, the expression means "I'm afraid".

These examples provide a glimpse of the symbolic and allegorical wealth of Réunion Creole; for the speakers of this language, such representations of what is inside the body end up becoming a part of their sense of reality.

These shifts in meaning, condensations and semantic confusions have implications concerning psychosomatic integration. Consider the example of a lady who had been marked, for more than thirty years, by her silent grief for her little boy. At the forefront of her request to receive psychological treatment was a multitude of diverse symptoms, which had been treated singly by her family doctor and several specialists. She suffered, among other things, from gastroesophageal reflux disease with heartburn. During our first meeting, we touched on the long-term consequences of traumatic grief on the entire family. I asked her: "Since then, has it been as if everyone in your family has been living with a coffin right there?" As I said "there", I pressed a hand against my own solar plexus, at the place where the heart and the stomach meet. The patient began to cry, liberated from a harsh pain that she (and her family) had been holding in since the death. She answered, "You know, in Creole, we say 'mon cœur $i$ saigne [my heart is bleeding].' Indeed, "mon cœur $i$ saigne".

\section{MR. LECORPS}

Next, we shall present a clinical picture in order to examine how such cultural material came into play during a course of psychotherapy, which took place in a community psychological and medical treatment center in Réunion.

Sixty-year old Mr. Lecorps ${ }^{2}$ had been treated at this center for many years before a psycho-motor therapist referred him for psychotherapy. The referring therapist stated that he had been disabled for a long time by a wide variety and large number of physical disturbances of unknown medical etiology. They had forced the patient to leave his position and eventually to be "reclassified" in another post that caused him less difficulty.

2 Translator's note: The pseudonym of this patient is based on the French word "corps," or "body" in English.
Mr. Lecorps had a slender silhouette and looked almost fragile, as his face showed pain in every move he had to make. He appeared to be clever, well-instructed, with a Master's degree, and insightful. Thus, he presented with a particularly pronounced speech disturbance, as if his voice had been worn out most of time, which made it very complicated for him to address others, even to his wife and children. At the outset, he explained that what was also causing him problems was the way that "my body plays tricks on me". Intrigued, I asked him to say more. "Sometimes", he replied,

when I decide to do something, I will walk over to do it and I wedge my foot [je me fais un cale-pied]... I mean, my foot does it to me, and I fall down. And sometimes I bite my tongue, or the inside of my cheeks or lip, without meaning to and without knowing I've done it. Until I start bleeding. I want to pick 
something up and my hand drops it. It's hard to deal with a body that just completely refuses to listen to me.

Although Mr. Lecorps was laughing as he described his bodily predicament, his annoyance and anxiety constantly came through in his narrative. He concluded by saying, " $M y$ body is my enemy".

We took up with him the question of the origin of these disturbances, and for Mr. Lecorps everything was clear. At the beginning of a particular day at his job, which had been a reward for his many years of university studies and competitive examinations, he had suddenly been gripped by an anxiety that was so intense that he could not start working. "It was like I suddenly understood that I wasn't supposed to be there, as if the idea that I was completely lying to myself by doing that just forced itself on me".

It should be noted that the patient's father had been a "prêt'malbar"or "pusari", an Indian priest, recognized for his power in the local community. Cold, hard and distant, he had had a period of major depression, which led to severe alcoholism. It was not easy for the patient to talk about his father, whom he remembered only as "being there, on the couch, and we often weren't sure whether he was dead or alive. We didn't pay attention to him anymore, so much so that he had even ceased to exist". This father was a part of the room, like the couch from which he did not get up, a simple "piece of furniture" ("meuble" in French, which also refers to human work force during slavery).

The mother was described in dual terms; she was loving, affectionate and omnipresent, but she also presented another face to him. This quite joyful and extroverted woman could suddenly turn off, and become nearly prostrate with anxiety and fear whenever she had to leave the family home and venture outside. Further, it was at these moments that the image by which he remembered his mother had become fixed: "As soon as we left the house, I would hold on to the hem of her skirt, like a transitional object that would protect me from others".

This notion of duality existed prior to Mr. Lecorps' childhood, for the distance between the inner face and the face shown to others echoed the duality of mind and body. If this patient often tended to intellectualize on this subject during his sessions, it seemed impossible for him to find a third path or voice for his being: inside there were a jovial mother and an almost moribund father, and outside a frightened mother and a powerful father. Mr. Lecorps spoke of Cartesian duality in relation to ideas about confrontation, opposition and contradiction. When we brought up the notion of paradox, he was able to reconcile his thoughts about himself.
He described his relationship with his mother as particularly fusional, which reappeared later in a "feeling of illegitimacy" and a sensation of being "there, in someone else's place". While these phrases could be read simply in Oedipal terms, it can also be said that, culturally, the patient found it impossible to anchor himself in his place in his lineage and within the cycle of reincarnation. These Oedipal and cultural approaches come together in the perspective of Hinduism, where filiation only involves the paternal line.

Mr. Lecorps compared his own memories of his childhood with the images of his mother's memories, which he had recently identified as involving emotional projections onto him:

At home, I was a real will-o'-the-wisp. Besides, my mother would complain because I wouldn't stay in place. But as soon as I left the house, I could no longer feel my body. It was as if it didn't exist anymore.

Mr. Lecorps went on to share a new memory of the schoolyard violence to which he had been subjected when he was young, at the hands of a certain "Octave" (we obviously asked the patient whether this name might be related to his voice symptom):

Strangely enough, even though he played dirty tricks on me, like tripping me or hitting me when he walked by me, I still liked Octave a lot. I admired him. He was everything I wasn't able to be. I liked that he gave himself permission to express, with so much conviction, all the violence that was inside him. And then, when he hit me, I existed, outside our house.

I suggested that perhaps the "tricks" his body played on him, just as he was on the verge of acting, could be a way of incorporating this Octave, as a sort of unattainable ideal. The tricks immediately stopped from this moment.

One day, Mr. Lecorps said that he did not experience any form of bodily pleasure, such that he did not even understand his wife's sexual needs, which he had trouble satisfying. He found it easier to respond "bodily than genitally" to his wife's solicitations of his love, the "bodily" response meaning non-sexual tenderness and affection. He explained that reading Spinoza had "dramatically changed everything in my life. That was when I told myself, 'that's what you ought to be'": a self-effacing, transparent ascetic. At no time did the patient realize that he was undergoing a gradual move towards Brahmanism! As Tarabout (2005) writes, "The Brahman's asceticism is not a constraint and even less a nuisance; it is an activity appreciated by the gods, who reward it by granting their favor" (para. 9). 


\section{THE ROLE OF THE PSYCHOSOMATIC IN PSYCHOTHERAPY}

Keller (2006) stresses how intrinsically difficult it is for human beings to conceive of themselves as a unicity of body and mind. He speaks of the importance of heeding the incessant speech that the subject produces about or addresses to his or her body, as well as the much more complex and personally unintelligible message that the body addresses to each subject.

Keller maintains that "for the human being, the bodyobject only exists when it receives a cultural seal, each culture being responsible for providing it with its own definition" (2006, p. 58).

Shweder (2008) writes: "When things go wrong for the people I know in rural India, when they have difficulties in life, when they suffer pain and anxiety, they wonder about their spiritual debts and they believe there is always something they can do to empower themselves and improve their prospects for the future" (p. 75). Shweder also explains that health disturbances in India can be investigated by "a "big three" set of explanations: biomedical tradition of medicine, interpersonal tradition ("the idea that one can be made sick by the envy or ill-will of relatives, neighbors, schoolmates, and colleagues who want the victim to die, suffer, fail, or fall under their influence"; p. 73) and moral tradition ("transgressions of obligation, omissions of duty, and ethical failures of all kinds"; p. 75).

Mr. Lecorps' psychotherapy, inspired by both psychodynamics and transcultural psychology, involved inducing him to recognize that the "battle" imposed on him by his body was a reflection of what he was fighting so fiercely against: his history, his origins, his family line, his culture, his religion, he status as a man, a brilliant, educated man. In short, Mr. Lecorps was at war with himself and seemed to be completely dissatisfied with himself. His process of individuation was at a stalemate. Although he was quick to tell his story in detail and with a wealth of strong psychical associations, it was impossible for him to connect all of this to himself, because none of it was agreeable to him. His body was trying to show him the extent to which this fight was foolish and the whole enterprise was pointless. So it played tricks on him....

What he did not say, but which was apparent to the psychologist, was that his body, situated on the low chair in the office, remained as rigid as a piece of wood ("ti paquet d'bois/d'riz", or a small package of wood/of rice, as is said of a baby who is carried around or set down somewhere). Further, at times, he was subject to fits of trembling, about which he did not speak, and it was even unclear whether he was aware of their existence. These bodily manifestations are reminiscent of the "sèzisman" (sudden chills of shock), which, in Réunion, can be evidence of traumatic fright or awe, and can also be a sign of a trance that appears during rituals when an ancestor takes over the believer's body and starts to "parler langaz" (to speak in ancestral tongues). This type of trance can be observed during both Tamil and Madagascan rituals, as well as during certain Catholic masses (such as the Mass for the Sick at the Eglise $d u$ Chaudron in the Chaudron quarter of Saint-Denis in Réunion). The patient found this comment, when it was made during the session, quite disturbing.

Fantasy has a very meaningful role in somatization (Bronstein, 2016). Donabédian (2016) explains that, in the dreams of "psychosomatic" patients, "if the fantasy is clearly identified by the ego, the maximal defense will be a vehement repression that impedes the whole of the subject's objectival and narcissistic libidinal life" (p. 23).

Mr. Lecorp's work on his intense dream activity, which was particularly rich in symbols, allowed him to reappropriate repressed aspects of himself. For example, at one point he spoke of a dream in which a father cut the neck of a chicken. He asked of his own accord: "Who is this father? Who is the chicken?". He verbalized his connection to Tamil sacrifice rituals, and this enabled him to speak again of the few times he had attended "services" presided over by his father. "I didn't like them. They were inhuman". He mentioned the "collective hysteria, this whole masquerade that tries to get rid of our own responsibility for what happens to us". Working on this dream allowed him to begin to reconcile himself with his vocal symptom. He shared his thoughts on the question of the "threat, the sword of Damocles". He then said that when he lost his voice, he had the impression that there was "a metallic object in my throat and I couldn't do anything other than swallow it." For him, "metallic"3 meant "cold, inhuman". This moment in his elaboration was a turning point in the psychotherapy: from then on, Mr. Lecorps was able to take up the issue of his own image, his self, his corporeality (or his "corps [body] orality", as his psycho-motor therapist put it to him.)

Smadja (2014) recalls that "one of the most surprising characteristics of somatization $[\ldots]$ is its projective character" (p. 17). The connection between these descriptions and those Mr. Lecorps used when describing his father and the rituals he practiced made it possible to link the symptom of biting his lip, inner cheek and tongue to his inability to appease family conflicts, in particular the "brutal" relationship between his wife and their children (which was not, strictly speaking, violent, but instead, involved his wife's affective distance towards the children, which he found difficult to accept).

We thus came full circle, for the patient was able to engage in a reflection on how what he had experienced was being transmitted to his own children. After two years

3 Note that in Réunion Creole, "un métallique" ("a metallic") refers to both the wire fencing that separates different parcels of land and the fencing used to construct shelters for animals, for cattle. 
of intensive treatment with near-weekly sessions, we came to the conclusion that the patient was in a persistent and perpetual conflict with every aspect of his origins: being the son of his father was so inconceivable to him that he never spoke spontaneously of the man, and being the child of a socially "mediocre" family was no more agreeable to him than was his own professional and familial success. Lastly, being a Malbar was unimaginable: "You know, a Malbar with his mustache and gold teeth down in the courtyard with a goat...everything I can't stand". All of this had a strong resonance with his bodily experience: "My body is my enemy", as he put it. Let us also recall that the Hindu view of conception involves a split between male and female gametes when the embryo is formed. This impossible incarnation was clearly connected with this patient's identity disturbances.

In Mr. Lecorps speech, parental imagoes were so forceful and immobile that, in many respects, they were evocative of Jungian parental complexes; they were so powerful that they left very little place for the child's physical and psychical existence outside their presence, gaze and actions. Mr. Lecorps had his own way of defining this: "Bad parents the ones who don't pay attention to what a child says, who ask a lot and give nothing in return, from whom nothing can be obtained." Freed from the yoke of what Jung called the "great mother", the patient could make a place for his father and come to consider himself as a father to his children (without running the risk of being a "bad parent"), a husband to his wife, and a man with a role in society.

The initial psychiatric diagnosis of this patient referred to a "dissociative conversion disorder" and "neurotic anxiety and phobia disturbances". Following psychotherapy, the psychiatrist noted that there had been an improvement of the general clinical picture, particularly with respect to the phonic symptom and the anxiety disturbances, along with the disappearance of depressive features and obsessions. Medications were reduced and eventually stopped completely.

As a psychologist, I found that it was very useful when speaking with Mr. Lecorps, who used the French language almost exclusively, to reintroduce the necessity of establishing connections [se relier, in the sense of the Latin root of the term religion, religere, religio, meaning "to tie fast, to tie up, to bind"] among different aspects of his linguistic and cultural heritage. This involved proposing words, expressions, sayings and proverbs that speak of the body and its manifestations, questioning them and letting them speak. This rendered dialogue, in Keller's sense, possible. At the same time, Réunion Creole, in all its symbolic power, provided ways of making subtle connections with the past and with culture, as well as with identity and the lack of determinism that is ultimately involved in its eternal process of construction. It could be said here that, in the end, Creole was the language of his psychical liberation: it not only bore the memories of the history of his ancestors and the heritage that they had bequeathed to him, but also opened up on a future that was specific to his own self. After working, in a dual perspective involving psychology and culture, to calm his massive infantile lived experience -which involved a restructuring of overpowering parental figures - the patient could consent to situating himself differently, thereby succeeding in accepting his history and what he had forgotten or ignored about the protagonists of his existence.

In such cases, the psychologist is called upon to modify his or her own position. Here, this involved giving meaning to a mind/body dialogue within a fabric of cultural representations and the web of identity, which exceeded both the clinician and the patient. It also involved speaking the patient's language, his own idiom, and appealing to the structure (which he did not know or had chosen to disregard) by which reality is inscribed culturally. These modifications had to be learned and discovered, in an effort to open oneself up to the other's internal world and his religious community. The psychologist has to search for cultural references (religion, meaningful traditions and historical facts) that are not necessarily his or her own. The psychologist has to be aware of the struggle for an existential synthesis in Reunionese culture, prone to induce suppression of multiple cultural legacies.

\section{CONCLUSION}

As this clinical illustration shows, psychological practice must listen, in what patients say, for inherited identity stigma and the suffering associated with it; the splitting that had once been imposed remains active, sometimes insidiously, and can lead to a sort of cultural eugenics. In this sense, the reality of the inhabitants of Réunion accords with that of members of every culture that has been marked, at some moment in its history, by a relation of violent domination. To try to provide a holistic perspective on the question of the "sense of identity", we could cite Ghasarian (2002), who highlights the constant reformulations (which move from attempts to establish cultural syncretisms to claims about the purity of the culture of origin) at work in Réunion society:

If cultural integration supposes that at least two cultural systems and models are present, such that one is imposed on the other, creolization involves instead a mixing of cultural models that ends in a compromise that takes a new form, which is more or less syncretic. Cultural reinvention, for its part, involves a manipulation of models that have been imposed and those that have emerged from forced contact, in order to produce, often quite explicitly, new social meanings. (Ghasarian, 2002, p. 663) 
In these efforts - these circuits from one pole to the other in the movement of identity construction - we can hear the confrontation between the attempt to forget the (painful, blurry, denied) past and the perpetual search for one's origins, which is universal and timeless. Such healing strategies seem ineffective: they repeat, concatenate, cancel one another out and then emerge again. Mr. Lecorps suffered terribly from being cut off from his origins, a rupture that was nonetheless necessary to his attempt to emerge as an individual self and rid himself of his trauma, his symbolic debts, his family history and rites, all of which were at work unbeknownst to him, and much to the annoyance of his own body. A course of treatment that took account of the singular aspects of Réunion, with a corresponding transcultural therapeutic attitude, allowed problematic elements to be addressed and elaborated in another manner.

\section{REFERENCES}

Benoist, J. (1996). Métissage, syncrétisme, créolisation: Métaphores et dérives. Etudes Créoles, 19(1), 47-60. Retrieved from http:// classiques.uqac.ca/contemporains/benoist_jean/Metissage_ syncretisme creolosation/metissage texte.html

Bonniol, J.-L. (2001). Introduction. In J.-L. Bonniol (Ed.), Paradoxes du métissage (pp. 7-23). Paris, France: Éditions du Comité des Travaux Historiques et Scientifiques.

Bronstein, C. (2016). Psychosomatique: Le rôle du phantasme inconscient. Revue Française de Psychosomatique, 50(2), 117-132. https://doi.org/10.3917/rfps.050.0117

Donabédian, D. (2016). Du fantasme en psychosomatique. Revue Française de Psychosomatique, 50(2), 19-34. https://doi. org/10.3917/rfps.050.0019

Ghasarian, C. (2002). La Réunion: Acculturation, créolisation et réinventions culturelles. Ethnologie Française, 32(4), 663-676. https://doi.org/10.3917/ethn.024.0663

Govindama, Y. (2002). Culture et unité somato-psychique. Enfances \& Psy, 20(4), 50-58. https://doi.org/10.3917/ep.020.0050

Govindama, Y. (2011). Le monde hindou et l'île de La Réunion. In Y. Govindama (Ed.), Temps et rites de passage (pp. 41-61). Paris, France: Éditions Karthala.

Grandidier, M. G. (1932). A Madagascar, anciennes croyances et coutumes. Journal de la Société des Africanistes, 2(2), 153-207. https://doi.org/10.3406/jafr.1932.1533

Honoré, D. (2002). Proverbes réunionnais: 715 proverbes et variantes. Sainte-Clotilde, Réunion, France: Éditions UDIR.

Keller, P.-H. (2006). Le dialogue du corps et de l'esprit. Paris, France: Éditions Odile Jacob.

Médéa, L. (2003). La construction identitaire dans la société réunionnaise. Journal des Anthropologues, 92-93, 261-281. doi: $10.4000 /$ jda.2013
Monier-Williams, M. (1899). A Sanskrit-English dictionary. Oxford, UK: Oxford University Press.

Pourchez, L. (2005). Métissages à la Réunion: Entre souillure et complexité culturelle. Africultures, 62(1), 46-55. https://doi. org/10.3917/afcul.062.0046

Shweder, R. A. (2008), The cultural psychology of suffering: The many meanings of health in Orissa, India (and elsewhere). Ethos, 36, 60-77. doi: 10.1111 / j.1548-1352.2008.00004.X

Smadja, C. (2014). Le modèle pulsionnel de la psychosomatique. Revue Française de Psychosomatique, 45(1), 11-30. https:// doi.org/10.3917/rfps.045.0011

Tarabout, G. (2005). Sans douleur. Systèmes de Pensée en Afrique Noire 17, 143-169. https://doi.org/10.4000/span.719

Tarabout, G. (2012). Quelques conceptions de la personne et de l'ancestralité en Inde. In D. Cupa, S. Dreyfus-Asséo, G. Tarabout, \& G. Chaudoye (Eds.), Les ancêtres (pp. 53-61). Paris, France: Éditions EDK.
Submitted: 02/05/2017

Reviewed: 29/05/2018

Accepted: 05/09/2018 